\title{
Adulthood asthma as a consequence of childhood adversity: a systematic review of epigenetically affected genes
}

\author{
Yasemin Saygideğer MD, PhD ${ }^{1-2}$, Hakan Özkan $M D^{3}$, Oya Baydar $M D^{1}$, Özge Yılmaz $M D^{4}$ \\ ${ }^{1}$ Department of Pulmonary, School of Medicine, Cukurova University, Adana, Turkey \\ ${ }^{2}$ Department of Translational Medicine, Graduate School of Health Sciences, Cukurova University, Adana, Turkey \\ ${ }^{3}$ Department of Pediatrics, Seyhan Education and Research Hospital, Baskent University, Adana, Turkey \\ ${ }^{4}$ Department of Pediatric Allergy and Immunology, School of Medicine, Celal Bayar University, Manisa, Turkey \\ Short Title: Child abuse, epigenetics and asthma
}

\section{Previous Abstract Presentations:}

Part of this work has been presented at Turkish Thoracic Society's 22 ${ }^{\text {nd }}$ Annual Congress in April 2019.

\section{Correspondence and organization:}

Yasemin Saygideğer, MD, PhD

e-mail: ysaygideger@cu.edu.tr

ORCID: 0000-0003-3293-373X 


\section{ABSTRACT:}

There is an accumulating data that shows relation between childhood adversity and vulnerability to chronic diseases as well as epigenetic influences that in turn give rise to these diseases. Asthma is one of the chronic diseases that is influenced from genetic regulation of the inflammatory biomolecules and therefore the hypothesis in this research was childhood adversity might have caused epigenetic differentiation in the asthma related genes in the population who had childhood trauma. To test this hypothesis, the literature was systematically reviewed to extract epigenetically modified gene data of the adults who had childhood adversity, and affected genes were further evaluated for their association with asthma. PRISMA guidelines were adopted and PubMed and Google Scholar were included in the searched databases, to evaluate epigenetic modifications in asthma related genes of physically, emotionally or sexually abused children. After retrieving a total of 12,085 articles, 36 of them were included in the study. Several genes and pathways that may contribute to pathogenesis of asthma development, increased inflammation or response to asthma treatment were found epigenetically affected by childhood traumas. Childhood adversity, causing epigenetic changes in DNA, may lead to asthma development or influence the course of the disease and therefore should be taken into account for the prolonged health consequences.

Key-words: Asthma, Epigenetics, child abuse, childhood adversity, asthma related genes, inflammation. 


\section{INTRODUCTION AND AIM:}

Chronic respiratory diseases, particularly asthma, is known to be regulated by cellular and immunologic responses to environmental and biological factors to varying degrees in different individuals. Prenatal in-utero stress, microbiota at birth or various postnatal factors such as nutrition, infections and second-hand smoke contribute to the development of these responses $^{1,2}$. Cumulative data also indicate a relation between early life adversities and chronic airway diseases. A summary of 8 population-based research articles that show association between respiratory diseases and childhood adversities are listed in Table $\mathbf{I}^{3-10}$. Six of these studies are cross-sectional and two of them are case control. These studies not only focus on asthma, but also other chronic disorders including COPD, cancer and immune system disorders. They have evaluated different types of adversities ranging from sexual and physical abuse to gun violence and emotional abuse in children, and the outcome revealed that there was a strong correlation between childhood adversities and presence of adulthood chronic respiratory diseases.

Child adversities are known as risk factors for psycho-social or mental disorders in different levels and found associated with addiction to smoke, alcohol or drugs ${ }^{11}$. In this context, search for the epigenetic changes in acute and chronic stress including childhood adversities revealed that the methylation status of various genes changes due to these childhood conditions ${ }^{12}$. The proposed pathways regarding epigenetic changes suggest that; stress activates hypothalamic pituitary adrenal axis (HPA axis) and this induce cortisol increase leading to direct or indirect regulation of immune system. 
The hypothesis of this research was, epigenetic changes might lead to asthma in abused children. Therefore, we systematically screened the studies that listed significantly affected genes from epigenetic changes associated with child abuse and then further evaluated for the role of these genes in asthma pathogenesis.

\section{METHODS:}

We followed PRISMA Statement ${ }^{13}$ for review of the literature for childhood adversity and asthma in population-based researches. We used keywords ("child abuse" OR "child adversity" OR "child sexual abuse" OR "child physical abuse" OR "child neglect" OR "child trauma") AND ("genetics" OR "epigenetics" OR (DNA Methylation)) in NCBI-PubMed and Google Scholar to bring together the informative data that shows relation between childhood adversity and epigenetic changes. Only original research articles were included; review articles, articles involving adversities that are occurred after age of 18 and articles that did not have the results of epigenetic analysis as well as the ones involving only economical adversities and pregnancy adversities were excluded. Initially, 12,085 articles were retrieved, and majority of those articles were excluded after reviewing the abstracts and titles. Among the 36 articles that were identified after this first review, 15 had whole genome methylation arrays and 21 had methylation data for single genes or pathways, given in the adopted PRISMA flowchart (Figure1). Finally, we extracted significantly methylated genes from each study and evaluated the functions of these genes on Gene Cards and NCBI Gene web sites in order to identify the relations with asthma. We also searched PubMed to assess in-vivo, in-vitro and clinical studies in 
relation with these differentially methylated genes and asthma. We then run a gene ontology analysis using an online too ${ }^{14}$ and visualized the pathways related with the evaluated genes.

\section{RESULTS}

After reviewing 36 full text articles, differentially methylated genes were recorded and analyzed for their role in asthma. The study sample sizes, methods, studied tissues, countries, and significantly differently methylated genes and their possible contribution to asthma is listed in Table-Il for 15 whole genome analysis or microarray studies. Twenty-two single gene or pathway studies are listed in supplementary table. All studies were performed in developed countries including USA, Canada, UK, and Netherlands etc. and they have extracted DNAs were from whole blood, saliva, T cells and monocytes. There was at least one affected gene related to asthma in each study while some of the studies showed multiple pathways involved in asthma pathogenesis affected (Table-II). Most studies had data for post-traumatic stress disorder genes and focused on hypothalamus - pituitary - adrenal (HPA) axis and immune system related genes, therefore, the genes that regulate HPA axis, NR3C1 and FKBP5, were the most well-studied genes. NR3C1 and FKBP5 are also involved in asthma pathogenesis by decreased suppression of inflammation and decrease response to corticosteroids respectively. Other significantly deregulated genes that were affected by childhood adversities were interleukins, ADAM family, WNT, STAT and MAPK pathway and inflammatory related genes (Table-II). Only one recent study had found no significant relation between childhood adversity and epigenetic regulation after applying multiple statistical corrections (Table-II). 


\section{$\underline{N R 3 C 1 \text { and Asthma }}$}

The NR3C1 gene encodes glucocorticoid receptor (GR), which has DNA binding, nuclear localization, ligand binding and two activation function domains, and has the ability to inhibit the expression of asthma related cytokines such as IL- $5^{29}$. IL-5 induces the activity of eosinophils in asthma, after being released from the active macrophages and T lymphocytes. IL-5 induced leukotrienes, therefore, causes asthmatic reactions and symptoms. In a recent bioinformatics study that evaluated ignored genes that might have a function in allergic asthma, NR3C1 was found to be downregulated ${ }^{30}$. It has also been shown that polymorphisms and mutations in specific sites of this gene has correlation with increase in TGF- $\beta$ expression in asthma patients ${ }^{31}$, which is a well-known mediator that leads smooth muscle proliferation and airway remodeling. Regarding the epigenetic regulation of $N R 3 C 1$, maternal stress during pregnancy, caused increased methylation in the umbilical cord blood mononuclear cells that cause decreased GR expression in the child, which may affect cytokine production and treatment response in the childhood asthma ${ }^{32}$.

\section{FKBP5 and Asthma}

FKBP5 or FK506-binding protein 51, is a member of immunophilin protein family that has peptidyl-prolyl isomerases to catalyze isomeric shape of proline amino acid and thus, act as cochaperon to assist protein folding in various proteins. Increased levels of protein is found in central and peripheric airway brushings of severe asthma patients comparing to healthy subjects $^{33}$. It also serves as a receptor for steroids and immune suppressive drugs and therefore, mostly studied for the effects of treatment response in asthma. FKBP5 express an inhibitory effect on GR function by binding to glucocorticoid-GR complex and delays nuclear translocation 
of the signal ${ }^{34}$. There are also other rules of this protein in different pathways related with asthma pathogenesis. Increased levels of FKBP5 induce T-cell proliferation and function by binding to calcineurin and activating NFAT (Nuclear factor of activated T-cells) pathway ${ }^{34}$. Besides, stress induced decrease in FKBP5 methylation, upregulated the protein levels in blood and immune cells and this increase in FKBP5 promotes NF-kB (nuclear factor kappa-light chain enhancer of activated B cells) mediated inflammation ${ }^{35}$. Thus, reduced methylation of FKBP5 in the abused children, might play role in the asthma development.

\section{FANK1 and Asthma}

The relationship of FANK1 (Fibronectin type 3 and ankyrin repeat domains protein 1) with asthma is not well-studied There are studies that suggest the role of FANK1 in inhibition or activation of apoptosis. It is known to be expressed mostly by testis cells, but recently shown to be present also in T cells, alveolar and epithelial cells of bronchi ${ }^{36}$. In a computational analysis of asthma related genes, FANK1 has come forward as one of the 10 genes found to be associated with asthma ${ }^{37}$. However, the functional relation currently remains unknown.

\section{CHRNA5 And Asthma}

CHRNA5 (Neuronal acetylcholine receptor subunit alpha-5), is a cholinergic nicotinic receptor gene that acts in opening ion channels on the plasma membrane after acetylcholine binding. Expression of the gene is mostly found in airway myocytes and epithelial cells throughout the lungs $^{38}$. In a meta-analysis that evaluate chromosome $15 q 25$ region and airflow obstruction, Asp389Asn missense single nucleotide polymorphism in CHRNA5 was associated with airflow obstruction in never smokers ${ }^{38}$. Silencing this gene in three-dimensional cell culture model, increased thickness of the epithelium, suggesting the lead to airway remodeling ${ }^{39}$. Studies show 
increased dependency to cigarette smoking in men $^{40-41}$ but there is no data that shows relation with epigenetic regulation of CHRNA5 and asthma but since genetically modification of the gene contributes airflow obstruction, and in vitro knock-down of the gene causes increased thickness in the airway models, it is possible that the increased methylation might contribute to asthma phenotype in the abused child.

\section{$\underline{A D A M s} 10$ and 17 and Asthma}

ADAM (A disintegrin and metalloproteinase domain containing protein) family proteins act as sheddase, with its adhesion and protease function, and shed various membrane proteins at the outer cell membrane that cause the maturation of those proteins and/or releasing them from the membrane. A single ADAM protein can cleave more than one protein as well as different ADAM members may cleave the same substrate. ADAM10 and ADAM17 have the similar active sites that both of them can cleave membrane bound TNF-alpha to its mature dissolvable state. ADAM10 has ability to shed ephrin/eph complexes between the cells, helps releasing soluble forms of IL6 and IL11 by mediating cleavage of IL6R and IL11RA, and also other surface proteins including heparin binding epidermal growth factor. ADAM10 also serves as a receptor for S. aureus, increasing the virulence of the bacteria. ADAM17 also cleaves IL6R, IL1RII, TGF-alpha, growth hormone receptor ${ }^{42}$. Obviously, there are other many proteins and pathways effected by these two ADAMs that are not listed here. Thus, ADAM 10 and 17 playing role in endothelial permeability, smooth muscle transactivation, leukocyte recruitment, preventing resolution of inflammation and inducing inflammation, are important proteins in asthma pathogenesis and might be target for the treatment of the disease. Loss of function mutations of ADAM10 and ADAM17 are extremely rare and mice with double knockout of these genes do not survive ${ }^{42}$. Overall, epigenetic regulation of these genes might affect asthma development in children. 


\section{$\underline{\text { SLC6A4 (SERT) and Asthma }}$}

SLC6A4 gene, encodes sodium dependent serotonin transporter and solute carrier family 6member 4 (also SERT or 5HT transporter) protein that involves in recycling of serotonin (5Hydroxy tryptamine, 5HT) molecules by transporting them from the synaptic area to the presynaptic membrane. $5 \mathrm{HT}$, besides its functions in the central nervous system, has ability to induce cytokine and chemokine synthesis, cell proliferation and tissue regeneration ${ }^{43}$, therefore, it is well studied in the pathogenesis of asthma. Increased levels of serotonin is found in symptomatic asthmatic patients and negatively correlated with FEV1 levels ${ }^{43}$. 5HT, stimulates PGE2 production by alveolar macrophages, activates eosinophils and suppress IL-12 expression $^{43}$. $5 \mathrm{HT}$ also act as a platelet-stored vasoconstrictor. Termination of the serotonin signal depends on the levels of SLC6A4 and activation of the receptor helps relief of asthma symptoms to release ${ }^{44}$. There are studies that evaluated the relationship between SLC6A4 gene polymorphisms and asthma but have not found any correlations up to now with the studied ones $^{45}$. SLC6A4 knockout mice show anxiety-like behavior and changes in the methylation of the gene may contribute the levels of $5 \mathrm{HT}$ and therefore influence asthma genotype in the maltreated and affected children.

\section{$\underline{\text { OXTR and Asthma }}$}

OXTR gene codes for oxytocin receptor, which is a $G$ protein coupled receptor that needs to activate phosphatidylinositol-calcium second messenger molecules. Studies have shown that OXTR is expressed both in human and mice airway smooth muscle cells and its expression is affected by cytokines such as IL-13 and TNF-alpha ${ }^{46}$. Oxytocine levels in BAL fluids were also 
found increased in asthmatic patients comparing to healthy control subjects ${ }^{46}$ suggesting that OXTR and its epigenetic regulation might have a role in the pathogenesis of asthma.

\section{$\underline{R P T O R, M T O R}$ and Asthma}

RPTOR or raptor (Regulatory-associated protein of mTOR), regulates mammalian target of rapamycin complex 1 (mTORC1) activity which involves in cell growth, survival and autophagy. It also has role in maintaining the size of the cell. It is mostly expressed in muscle cells including lungs. In a study that evaluate airway smooth muscle tissue with RNA sequencing to compare asthmatic and normal people, RPTOR was found one of the four genes which were associated with airway hyper-responsiveness ${ }^{47}$. mTOR (mechanistic target of rapamycin kinase), was also found to involve in airway remodeling models in mouse models as well as regulation of Th17/Treg and Th1/Th2 ratio $^{48}$. Therefore, epigenetic regulation of mTOR and related pathways significantly influence asthma development.

\section{$\underline{R G S 3 \text { and } H C K \text { and Asthma }}$}

RGS3 involves in inflammation and T cell migration ${ }^{49}$ and HCK takes plays in MAPK signaling pathway which in turn related with airway smooth muscle proliferation ${ }^{50}$. Labonte et al found these two genes were significantly hypermethylated in the brain tissue of the traumatic children, but currently there is no data that shows the epigenetic change in the blood or other tissues in these two genes.

\section{$\underline{C X C L 10 \text { and Asthma }}$}

C-X-C motif chemokine ligand 10 (IFN-gamma-induced protein 10 (IP-10) or small inducible cytokine B10) is a small protein coded by $C X C L 10$ gene. It is expressed in monocytes, endothelial 
cells and fibroblasts and has a variety of role in the inflammation. Therefore, the effects on the asthma pathogenesis is well-studied. mRNA levels of CXCL10 were found increased in bronchoalveolar fluid of asthmatic patients and data suggest that it has role in corticosteroid therapy induced persistent type I inflammation ${ }^{51}$. Kaufman J et al, evaluated epigenetic influences on the obesity in adverse childhood experienced children and found decreased methylation of the promoter region of CXCL10. Therefore, inducing obesity or involving inflammation, epigenetic regulation of the gene may contribute to asthma development in the abused children.

\section{STAT and Asthma}

STAT family of proteins (signal transducer and activator of transcription) act as transcription factors after extracellular cytokine or growth factor binding in the cell and lead to the expression of proliferation, differentiation and apoptosis related genes. STAT1 was reported one of the asthma-ignorome gene together with $N R 3 C 1^{30}$ and variants of STAT6 found related with risk for asthma in a meta-analysis study ${ }^{52}$. Epigenetic regulation of Jak-STAT pathway in childhood asthma has been recently reported ${ }^{53}$.

\section{$\underline{\text { CREB and Asthma }}$}

CREB (CAMP response element-binding protein) is another transcription factor that regulate expression or suppression of multiple genes after getting activated by upstream signaling pathways those use CAMP as secondary messenger. Therefore, it involves multiple pathways in Asthma signaling including therapy response ${ }^{54}$.

\section{$\underline{N F K B, I K a p p a B R \text { and Asthma }}$}


NF-KB (nuclear factor kappa-light chain enhancer of activated B cells), consists of protein to regulate transcription, cytokine production and survival when the cell is under stress. Together with MAPK pathway, epigenetic regulation of NF-KB signaling was found significantly affected in adult-onset asthma ${ }^{55}$. Researchers have been interested in targeting NF-KB for asthma treatment for the last years. IKappaBR (IKBR) or TONSL gene codes for Tonsoku like DNA Repair protein that negatively regulate NFKB mediated transcription. Therefore, increased methylation of IKBR and demethylation of NFKB would worsen asthma phenotype in the maltreated children.

\section{$\underline{A L D H 2 \text { and Asthma }}$}

$\mathrm{ALDH} 2$ (acetaldehyde dehydrogenase 2 ) is a member of ALDH family of proteins that acts as an antioxidant and its increased expression inhibits the harmful effects of oxidative stress. Polymorphisms of the gene may cause premature lung aging ${ }^{56}$ and ALDH2-deficient mice had alcohol induced asthma in an animal model study ${ }^{57}$. These and several other studies indicate that increased methylation of $A L D H 2$ may have role in the asthma pathogenesis.

\section{MAPK pathhway, NPY - FOXP4 and Asthma}

Mitogene activated protein kinase (MAPK) pathway is a series of signaling cascade pathways that induce distinct pathways in the cell regarding differentiation, proliferation and cell survival. Its role in asthma pathogenesis has been shown and reviewed in the literature ${ }^{58}$.

NPY (Neuropeptid Y), involves in multiple signaling pathways including MAPK pathway and it also regulates intracellular calcium levels. The expression levels of NPY on antigen presenting cells (APCs) in allergic asthma has been shown and its role on cytokine expression is not yet clear $^{59}$. In a study, the loss of FOXP4 (Forkhead box protein 4) together with FOXP1, which are 
transcription factors located in airway cells, led to increased NYP expression resulting in airway hyperreactivity through activation of smooth muscle myosin light-chain phosphorylation ${ }^{60}$.

\section{$\underline{A T P 2 A 3 \text { and Asthma }}$}

ATP2A3 (Sarcoplasmic / Endoplasmic Reticulum Calcium ATPase 3), involving intracellular calcium levels, influence a variety of signaling pathways. the expression was shown to vary among different childhood asthma phenotypes ${ }^{61}$.

Other relevant genes and gene ontology and pathway analysis

The rest of the genes listed in Table-II are usually found in the literature That assessed obesity asthma relationship or that took place in the gene expression pathways in immune system.

After reviewing these genes in the literature, we further ran a gene ontology (GO) analysis using two different online tools $s^{62-14}$ and visualized the pathways related with the evaluated genes (Figure-2 \& Supplementary material-1).

\section{DISCUSSION \& CONCLUSION}

In this research, we demonstrated that childhood adversity, including sexual and physical abuse and neglect, effects the epigenetic regulation of asthma related genes. These epigenetic changes focused on altered methylation of DNA, which has become convenient to study comparing to chromatin purification ${ }^{63}$. The increased or decreased methylation of the genes found in the adults, who experienced adverse childhood events, were included well studied asthma related genes such as $A D A M 10 \& 17$ and $C X C L 10$ as well as the genes that seemed less 
common in asthma pathogenesis regarded studies such as ALDH2, FOXP4, and FANK1. Up to date scientific investigations of asthma pathogenesis indicate a multi-complex pathophysiologic process that might be responsible of the diverse phenotypes among asthma patients and recent studies indicate a contribution of lifelong epigenetic influences to this pathophysiology ${ }^{64}$. The complexity increases while the type of the adversity and its relationship with asthma may differ from population to population, related to cultures and traditions, and therefore, limitation of this systematic review is that the origin of most studies included the countries with similar socioeconomic background decreasing the value of generalizability. This study also did not include in-utero period of the children, which may also contribute to epigenetic alterations. Although the genes listed in this study have been associated with asthma and a few of them are well-studied, the underlying pathway for these associations may need deeper research for future discoveries of personalized medicine and to understand the pathogenesis of the relationship of these epigenetic influences with asthma.

\section{Acknowledgements}

Author Contributions: YS designed the study analyzed the results and wrote the manuscript; $\mathrm{HO}$ and $\mathrm{OB}$ involved in literature search and data collection; OY critically reviewed the manuscript.

Financial Support: None

Conflict of Interest: All authors declare no support, financial or otherwise, from any organization for the submitted work. 
medRxiv preprint doi: https://doi.org/10.1101/2021.07.01.21259888; this version posted July 5, 2021. The copyright holder for this preprint (which was not certified by peer review) is the author/funder, who has granted medRxiv a license to display the preprint in perpetuity. It is made available under a CC-BY-NC-ND 4.0 International license . 


\section{REFERENCES:}

1. Carraro, S., Scheltema, N., Bont, L., \& Baraldi, E. (2014). Early-life origins of chronic respiratory diseases: understanding and promoting healthy ageing. Eur Respir J., 44(6), 1682-1696. doi:10.1183/09031936.00084114

2. Zhang, Y., \& Kutateladze, T. G. (2018). Diet and the epigenome. Nat Comm., 9(1). doi:10.1038/s41467-018-05778-1

3. Shields, M. E., Hovdestad, W. E., Pelletier, C., Dykxhoorn, J. L., O’Donnell, S. C., \& Tonmyr, L. (2016). Childhood maltreatment as a risk factor for diabetes: findings from a population-based survey of Canadian adults. BMC Public Health, 16(1). doi:10.1186/s12889-016-3491-1

4. Bhan, N., Glymour, M. M., Kawachi, I., \& Subramanian, S. V. (2014). Childhood adversity and asthma prevalence: evidence from 10 US states (2009-2011). BMJ Open Respiratory Research, 1(1), e000016. doi:10.1136/bmjresp-2013-000016

5. Ayaydin, H., Abali, O., Okumus Akdeniz, N., Kok, B. E., Gunes, A.,Yildirim, A., Deniz, G. (2016) Immune system changes after sexual bause in adolescents. Pediatr. Int. (2016) 58, 105-112. Doi: 10.111/ped.12767.

6. Remigio-Baker, R. A., Hayes, D. K., \& Reyes-Salvail, F. (2015). Adverse Childhood Events are Related to the Prevalence of Asthma and Chronic Obstructive Pulmonary Disorder 
Among Adult Women in Hawaii. Lung, 193(6), 885-891. doi:10.1007/s00408-015-9777-

8

7. Clemens, V., Huber-Lang, M., Plener, P. L., Brähler, E., Brown, R. C., \& Fegert, J. M. (2018). Association of child maltreatment subtypes and long-term physical health in a German representative sample. Eur J Psychotraumatol., 9(1),

1510278. doi:10.1080/20008198.2018.1510278

8. Rosas-Salazar, C., Han, Y.-Y., Brehm, J. M., Forno, E., Acosta-Pérez, E., Cloutier, M. M.,et al. (2016). Gun Violence, African Ancestry, and Asthma. Chest, 149(6), 14361444. doi:10.1016/j.chest.2016.02.639

9. Bonfim, C. B., dos Santos, D. N., \& Barreto, M. L. (2015). The association of intrafamilial violence against children with symptoms of atopic and non-atopic asthma: A crosssectional study in Salvador, Brazil. Child Abuse \& Neglect, 50, 244253. doi:10.1016/j.chiabu.2015.05.021

10. Bellis, M. A., Hughes, K., Leckenby, N., Hardcastle, K. A., Perkins, C., \& Lowey, H. (2014). Measuring mortality and the burden of adult disease associated with adverse childhood experiences in England: a national survey. J Public Health, 37(3), 445454. doi:10.1093/pubmed/fdu065

11. Sinha, R. (2008). Chronic Stress, Drug Use, and Vulnerability to Addiction. Ann NY Acad Sci., 1141(1), 105-130. doi:10.1196/annals.1441.030 
12. Yang, B.-Z., Zhang, H., Ge, W., Weder, N., Douglas-Palumberi, H., Perepletchikova, F., et al. (2013). Child Abuse and Epigenetic Mechanisms of Disease Risk. Am J Prev Med., 44(2), 101-107. doi:10.1016/j.amepre.2012.10.012

13. Moher D, Liberati A, Tetzlaff J, Altman DG. The PRISMA group (2009). Preferred reporting items for Systematic Reviews and Meta-Analyses: The PRISMA Statement. PLoS Med Doi: 10.1371/journal.pmed1000097.

14. Pomaznoy M, Ha B, Peters B. GOnet: a tool for interactive gene Ontology analysis. BMC Bioinformatics. 2018;19:470. Doi: 10.1186/s12859-018-2533-3.

15. Mehta, D., Klengel, T., Conneely, K. N., Smith, A. K., Altmann, A., Pace, T. W. et al. (2013). Childhood maltreatment is associated with distinct genomic and epigenetic profiles in posttraumatic stress disorder. Proc Natl Acad Sci USA., 110(20), 83028307. doi:10.1073/pnas.1217750110

16. Provençal, N., Suderman, M. J., Caramaschi, D., Wang, D., Hallett, M., Vitaro, F. et al. (2013). Differential DNA Methylation Regions in Cytokine and Transcription Factor Genomic Loci Associate with Childhood Physical Aggression. PLoS ONE, 8(8), e71691. doi:10.1371/journal.pone.0071691

17. Guillemin, C., Provençal, N., Suderman, M., Côté, S. M., Vitaro, F., Hallett, M. et al. (2014). DNA Methylation Signature of Childhood Chronic Physical Aggression in T Cells of Both Men and Women. PLoS ONE, 9(1), e86822. doi:10.1371/journal.pone.0086822 
18. Provençal, N., Suderman, M. J., Guillemin, C., Vitaro, F., Côté, S. M., Hallett, M. et al. (2014). Association of Childhood Chronic Physical Aggression with a DNA Methylation Signature in Adult Human T Cells. PLoS ONE, 9(4), e89839. doi:10.1371/journal.pone.0089839

19. Suderman, M., Borghol, N., Pappas, J. J., Pinto Pereira, S. M., Pembrey, M., Hertzman, C. et al. (2014). Childhood abuse is associated with methylation of multiple loci in adult DNA. BMC Medical Genomics, 7(1). doi:10.1186/1755-8794-7-13

20. Labonté , B., Turecki, G. (2012) Epigenetic Effects of Childhood Adversity in the Brain and Suicide Risk. The Neurobiological Basis of Suicide. Boca Raton (FL): CRC Press/Taylor \& Francis; 2012. Chapter 13. Frontiers in Neuroscience. PMID: 23035281 Bookshelf ID: NBK107193

21. Schwaiger, M., Grinberg, M., Moser, D., Zang, J. C. S., Heinrichs, M., Hengstler, J. G. et al. (2016). Altered Stress-Induced Regulation of Genes in Monocytes in Adults with a History of Childhood Adversity. Neuropsychopharmacology, 41(10), 25302540. doi:10.1038/npp.2016.57

22. Cicchetti, D., Hetzel, S., Rogosch, F. A., Handley, E. D., Toth, S. L.(2016). An investigation of child maltreatment and epigenetic mechanisms of mental and physical health risk. Dev Psychopathol, 28(4pt2), 13051317. doi:10.1017/s0954579416000869

23. Cecil, C. A. M., Smith, R. G., Walton, E., Mill, J., McCrory, E. J., Viding, E. (2016). Epigenetic signatures of childhood abuse and neglect: Implications for 
psychiatric vulnerability. J Psychiatr Res., 83, 184-

194. doi:10.1016/j.jpsychires.2016.09.010

24. Kaufman, J., Montalvo-Ortiz, J. L., Holbrook, H., O’Loughlin, K., Orr, C., Kearney, C. et al. (2018). Adverse Childhood Experiences, Epigenetic Measures, and Obesity in Youth. J Pediatr. ,202:150-156.e3, doi:10.1016/j.jpeds.2018.06.051

25. Marzi, S. J., Sugden, K., Arseneault, L., Belsky, D. W., Burrage, J., Corcoran, D. L. et al. (2018). Analysis of DNA Methylation in Young People: Limited Evidence for an Association Between Victimization Stress and Epigenetic Variation in Blood. Am J Psychiatry, 175(6), 517-529. doi:10.1176/appi.ajp.2017.17060693

26. Houtepen, L. C., Hardy, R., Maddock, J., Kuh, D., Anderson, E. L., Relton, C. L. et al. (2018). Childhood adversity and DNA methylation in two population-based cohorts. Translational Psychiatry, 8(1). doi:10.1038/s41398-018-0307-3

27. Marinova, Z., Maercker, A., Küffer, A., Robinson, M. D., Wojdacz, T. K., Walitza, S. et al.(2017). DNA methylation profiles of elderly individuals subjected to indentured childhood labor and trauma. BMC Medl Genet., 18(1). doi:10.1186/s12881-017$0370-2$

28. Khulan, B., Manning, J. R., Dunbar, D. R., Seckl, J. R., Raikkonen, K., Eriksson, J. G., \& Drake, A. J. (2014). Epigenomic profiling of men exposed to early-life stress reveals DNA methylation differences in association with current mental state. Translational Psychiatry, 4(9), e448-e448. doi:10.1038/tp.2014.94 
29. Panek, M., Jonakowski, M., ZioŁo, J., Wieteska, Ł., MaŁachowska, B., Pietras, T. et al. (2016). A novel approach to understanding the role of polymorphic forms of the NR3C1 and TGF- $\beta 1$ genes in the modulation of the expression of IL-5 and IL-15 mRNA in asthmatic inflammation. Mol Med Reports, 13(6), 4879-

4887. doi:10.3892/mmr.2016.5104

30. Riba, M., Garcia Manteiga, J. M., Bošnjak, B., Cittaro, D., Mikolka, P., Le, C. et al. (2016). Revealing the acute asthma ignorome: characterization and validation of uninvestigated gene networks. Scientific Reports, 6(1). doi:10.1038/srep24647

31. Panek, M., Pietras, T., Fabijan, A., Zioło, J., Wieteska, Ł., Małachowska, B. et al. (2015). The NR3C1 Glucocorticoid Receptor Gene Polymorphisms May Modulate the TGF-beta mRNA Expression in Asthma Patients. Inflammation, 38(4), 14791492. doi:10.1007/s10753-015-0123-3

32. Al-Hussainy, A., \& Mohammed, R. (2020). Consequences of maternal psychological stress during pregnancy for the risk of asthma in the offspring. Scand J Immunol. doi:10.1111/sji.12919

33. Singhania, A., Rupani, H., Jayasekera, N., Lumb, S., Hales, P., Gozzard, N. et al. (2017). Altered Epithelial Gene Expression in Peripheral Airways of Severe Asthma. PLOS ONE, 12(1), e0168680. doi:10.1371/journal.pone.0168680 
34. Zannas, A. S., Wiechmann, T., Gassen, N. C., \& Binder, E. B. (2015). Gene-StressEpigenetic Regulation of FKBP5: Clinical and Translational Implications. Neuropsychopharmacolo, 41(1), 261-274. doi:10.1038/npp.2015.235

35. Zannas, A. S., Jia, M., Hafner, K., Baumert, J., Wiechmann, T., Pape, J. C.,et al.(2019). Epigenetic upregulation of FKBP5 by aging and stress contributes to $N F-\kappa B-$ driven inflammation and cardiovascular risk. PNAS., 201816847. doi:10.1073/pnas.1816847116

36. Wu C, Orozco C, Boyer J, Leglise M, Goodale J, Batalow S et al. BioGPS: an extensible and customizable portal for querying and organizing gene annotation resources. Web page last accession date: 02.02.2021. (http://biogps.org/\#goto=genereport\&id=92565)

37. Tremblay, K., Lemire, M., Potvin, C., Tremblay, A., Hunninghake, G. M., Raby, B. A., et al. (2008). Genes to Diseases (G2D) Computational Method to Identify Asthma Candidate Genes. PLoS ONE, 3(8), e2907. doi:10.1371/journal.pone.0002907

38. Wilk, J. B., Shrine, N. R. G., Loehr, L. R., Zhao, J. H., Manichaikul, A., Lopez, L. M.,et al. (2012). Genome-Wide Association Studies IdentifyCHRNA5/3andHTR4in the Development of Airflow Obstruction. Am J Respir Crit Care Med., 186(7), 622632. doi:10.1164/rccm.201202-0366oc .

39. Krais, A. M., Hautefeuille, A. H., Cros, M.-P., Krutovskikh, V., Tournier, J.-M., Birembaut, P.,et al.(2011). CHRNA5 as negative regulator of nicotine signaling in normal and cancer bronchial cells: effects on motility, migration and p63 expression. Carcinogenesis, 32(9), 1388-1395. doi:10.1093/carcin/bgr090 
40. Xie, P., Kranzler, H. R., Zhang, H., et al. (2011). Childhood Adversity Increases Risk for Nicotine Dependence and Interacts with $\alpha 5$ Nicotinic Acetylcholine Receptor Genotype Specifically in Males. Neuropsychopharmacology, 37(3), 669-

676. doi:10.1038/npp.2011.240

41. Zhang, N.-Z., Chen, X.-J., Mu, Y.-H., \& Wang, H. (2018). Identification of differentially expressed genes in childhood asthma. Medicine, 97(21),

e10861. doi:10.1097/md.0000000000010861

42. Dreymueller, D., Uhlig, S., \& Ludwig, A. (2015). ADAM-family metalloproteinases in lung inflammation: potential therapeutic targets. Am J Physiol Lung Cell Mol Physiol., 308(4), L325-L343. doi:10.1152/ajplung.00294.2014

43. Kang, B. N., Ha, S. G., Bahaie, N. S., Hosseinkhani, M. R., Ge, X. N., Blumenthal, M. N.,et al. (2013). Regulation of Serotonin-Induced Trafficking and Migration of Eosinophils. PLoS ONE, 8(1), e54840. doi:10.1371/journal.pone.0054840

44. Flanagan, T. W., Sebastian, M. N., Battaglia, D. M., Foster, T. P., Cormier, S. A., \& Nichols, C. D. (2019). 5-HT2 receptor activation alleviates airway inflammation and structural remodeling in a chronic mouse asthma model. Life Sci, 116790. doi:10.1016/j.lfs.2019.116790

45. Farjadian, S., Moghtaderi, M., Fakhraei, B., Nasiri, M., \& Farjam, M. (2013). Association between serotonin transporter gene polymorphisms and childhood 
asthma. Journal of Asthma, 50(10), 1031-

1035. doi:10.3109/02770903.2013.834503

46. Amrani, Y., Syed, F., Huang, C., Li, K., Liu, V., Jain, D., et al.(2010). Expression and activation of the oxytocin receptor in airway smooth muscle cells: Regulation by TNF $\alpha$ and IL-13. Respir Res., 11(1). doi:10.1186/1465-9921-11-104

47. Yick, C. Y., Zwinderman, A. H., Kunst, P. W., Grünberg, K., Mauad, T., Chowdhury, S.,et al. (2014). Gene expression profiling of laser microdissected airway smooth muscle tissue in asthma and atopy. Allergy, 69(9), 1233-1240. doi:10.1111/all.12452

48. Zhang, Y., Jing, Y., Qiao, J., Luan, B., Wang, X., Wang, L., \& Song, Z. (2017). Activation of the mTOR signaling pathway is required for asthma onset. Sci Rep., 7(1). doi:10.1038/s41598-017-04826-y

49. Williams, J. W., Yau, D., Sethakorn, N., Kach, J., Reed, E. B., Moore, T. V., et al. (2013). RGS3 controls T lymphocyte migration in a model of Th2-mediated airway inflammation. Am J Physiol Lung Cell Mol Physiol, 305(10), L693L701. doi:10.1152/ajplung.00214.2013

50. Sakai, H., Nishimura, A., Watanabe, Y., Nishizawa, Y., Hashimoto, Y., Chiba, Y., \& Misawa, M. (2010). Involvement of Src family kinase activation in angiotensin IIinduced hyperresponsiveness of rat bronchial smooth muscle. Peptides, 31(12), 22162221. doi:10.1016/j.peptides.2010.09.012 
51. Gauthier M, Chakraborty K, Oriss TB., Raundhal, M.,Das, S., Chen, J., et al. Severe asthma in humans and mouse model suggests a CXCL10 signature underlies corticosteroid resistant Th1 bias. JCI Insight. 2017;2(13): e94580. Doi: 10.1172/jci.insight. 94580

52. Qian, X., Gao, Y., Ye, X., \& Lu, M. (2014). Association of STAT6 variants with asthma risk: A systematic review and meta-analysis. Hum Immunol., 75(8), 847853. doi:10.1016/j.humimm.2014.06.007

53. Zhang, N.-Z., Chen, X.-J., Mu, Y.-H., \& Wang, H. (2018). Identification of differentially expressed genes in childhood asthma. Medicine, 97(21),

e10861. doi:10.1097/md.0000000000010861

54. Kim, D., Cho, S., Woo, J. A., \& Liggett, S. B. (2018). A CREB-mediated increase in miRNA let-7f during prolonged $\beta$-agonist exposure: a novel mechanism of $\beta 2$-adrenergic receptor down-regulation in airway smooth muscle. The FASEB J., 32(7), 36803688. doi:10.1096/fj.201701278r

55. Jeong, A., Imboden, M., Ghantous, A., Novoloaca, A., Carsin, A.-E., Kogevinas, M., et al. (2019). DNA Methylation in Inflammatory Pathways Modifies the Association between BMI and Adult-Onset Non-Atopic Asthma. Int J Environ Res Public Health, 16(4), 600. doi:10.3390/ijerph16040600 
56. Kuroda, A., Hegab, A. E., Jingtao, G., Yamashita, S., Hizawa, N., Sakamoto, T.,et al. (2017). Effects of the common polymorphism in the human aldehyde dehydrogenase 2 (ALDH2) gene on the lung. Respir Res, 18(1). doi:10.1186/s12931-017-0554-5

57. Shimoda, T., Obase, Y., Matsuse, H., Asai, S., \& Iwanaga, T. (2016). The Pathogenesis of Alcohol-Induced Airflow Limitation in Acetaldehyde Dehydrogenase 2-Deficient Mice. Intl Arch Allergy Immunol, 171(3-4), 276-284. doi:10.1159/000452709

58. Chung, K. F. (2011). p38 Mitogen-Activated Protein Kinase Pathways in Asthma and COPD. Chest, 139(6), 1470-1479. doi:10.1378/chest.10-1914

59. Makinde, T. O., Steininger, R., \& Agrawal, D. K. (2013). NPY and NPY receptors in airway structural and inflammatory cells in allergic asthma. Exp Mol Pathol., 94(1), 45-50. doi:10.1016/j.yexmp.2012.05.009

60. Li S, Koziol-White C, Jude J, Jiang, M.,Zhao, H., Cao, G., et al. Epithelium-generated neuropeptide $\mathrm{Y}$ induces smooth muscle contraction to promote airway hyperresponsiveness. J Clin Invest. 2016;126(5):1978-1982. Doi: 10.1172/JCI81389.

61. Boeck, A., Landgraf-Rauf, K., Vogelsang, V., Siemens, D., Prazeres da Costa, O., Klucker, E.,et al. (2018). Ca2+ and innate immune pathways are activated and differentially expressed in childhood asthma phenotypes. Pediatr Allergy Immunol. doi:10.1111/pai.12971 
62. Fabregat, A., Sidiropoulos, K., Viteri, G., Forner, O., Marin-Garcia, P., Arnau, V., et al. (2017). Reactome pathway analysis: a high-performance in-memory approach. BMC Bioinformatics, 18(1). doi:10.1186/s12859-017-1559-2

63. DeVries A and Vercelli D. Epigenetic Mechanisms in Asthma. Ann. Am Thorac Soc. 2016 Mar; 13(Suppl 1): S48-S50. Doi: 10.1513/AnnalsATS.201507-420MG.

64. Chogtu B, Bhattacharjee D and Magazine R. Epigenetics: The new frontier in the landscape of asthma. Scientifica. Vol. 2016 Article ID 4638949, 7 pages. Doi: $10.1155 / 2016 / 4638949$

\section{Figure Legends}

Fig. 1. Adopted PRISMA Flowchart as of date 18 Decemeber 2019.

Fig. 2. Gene enrichment and pathway analysis of the affected genes. Differentially methylated genes in the adults who had childhood adversity, that have relationship with asthma are shown in orange color and significantly related pathways are in green. Dark green shows strongest relation. The full list of the pathways and corresponding full image are given in supplementary material. 
Table I. Studies introduce relation with child abuse and respiratory diseases

\begin{tabular}{|c|c|c|c|c|}
\hline $\begin{array}{l}\text { Author, } \\
\text { Year }\end{array}$ & Method & Sample Size & Trauma Type & $\begin{array}{l}\text { Significant outcome } \\
\text { for respiratory } \\
\text { system }\end{array}$ \\
\hline Shields, 2016 [3] & Cross-sectional & 15902 & Childhood physical abuse, sexual abuse, & COPD \\
\hline Bahn, 2014 [4] & Cross- sectional & 84786 & $\begin{array}{l}\text { Child sexual abuse } \\
\text { And physical abuse }\end{array}$ & Asthma \\
\hline Ayaydin,2016 [5] & Case-control & 43 & Child sexual abuse & $\begin{array}{l}\text { Immune system } \\
\text { disorders }\end{array}$ \\
\hline $\begin{array}{c}\text { Remigio-Baker } \\
2015[6]\end{array}$ & Cross-sectional & 3363 & $\begin{array}{l}\text { Physical abuse } \\
\text { Verbal abuse } \\
\text { Sexual abuse }\end{array}$ & $\begin{array}{l}\text { COPD } \\
\text { Asthma }\end{array}$ \\
\hline Clemens, 2018 [7] & Cross-sectional & 2510 & $\begin{array}{c}\text { Child maltreatment } \\
\text { (sexual, emotional, physical bause, } \\
\text { neglect) }\end{array}$ & $\begin{array}{l}\text { Obesity } \\
\text { COPD }\end{array}$ \\
\hline Salazar, 2016 [8] & Case-control & 747 & Gun violence & Asthma \\
\hline Bonfim, 2015 [9] & Cross-sectional & 1370 & İntrafamilal violence & Asthma \\
\hline Bellis, 2014[10] & Cross-sectional & 3885 & Child abuse & $\begin{array}{c}\text { Cancer } \\
\text { Resp. disease }\end{array}$ \\
\hline
\end{tabular}




\begin{tabular}{|c|c|c|c|c|c|c|c|c|}
\hline Article & $\begin{array}{l}\text { Definition of } \\
\text { Child } \\
\text { Maltreatment }\end{array}$ & $\begin{array}{l}\text { Sample } \\
\text { size }\end{array}$ & Country & $\begin{array}{l}\text { Age at the } \\
\text { time of DNA } \\
\text { sampling } \\
\text { (Mean or } \\
\text { range) }\end{array}$ & Tissue & Study design & $\begin{array}{l}\text { Significantly } \\
\text { differently } \\
\text { methylated } \\
\text { asthma } \\
\text { related } \\
\text { genes }\end{array}$ & $\begin{array}{l}\text { Possible outcome for } \\
\text { asthma }\end{array}$ \\
\hline Yang et al. [12] & $\begin{array}{l}\text { Reported case } \\
\text { records }\end{array}$ & $\begin{array}{l}96 \text { cases } \\
96 \text { contol }\end{array}$ & USA & $\begin{array}{l}10,2 \\
(5 \text { to } 14)\end{array}$ & Saliva & $\begin{array}{l}\text { Whole genome } \\
\text { methylation arrays }\end{array}$ & $\begin{array}{l}\text { FANK-1 } \\
\text { WNT } \\
\text { pathway } \\
\text { IL12B }\end{array}$ & $\begin{array}{l}\text { increased cell } \\
\text { differantiation in the } \\
\text { airway epithelium, } \\
\text { increased inflammation }\end{array}$ \\
\hline Mehta et al. [15] & $\begin{array}{l}\text { Childhood } \\
\text { trauma } \\
\text { questionnaire }\end{array}$ & $\begin{array}{l}32 \text { cases } \\
29 \\
\text { controls }\end{array}$ & USA & $\begin{array}{l}39,56 \\
\text { (cases) } \\
43.69 \\
\text { (controls) } \\
\end{array}$ & Blood & $\begin{array}{l}\text { whole genome } \\
\text { methylation arrays }\end{array}$ & $\begin{array}{l}\text { IL5RA } \\
\text { IL8 } \\
\text { ADAM10 } \\
\text { ADAM17 }\end{array}$ & $\begin{array}{l}\text { incerased } \\
\text { inflammation,increased } \\
\text { trans-endothelial } \\
\text { leukocyte migration, } \\
\text { epithelial permeability }\end{array}$ \\
\hline $\begin{array}{l}\text { Provençal et al. } \\
{[16]}\end{array}$ & $\begin{array}{l}\text { Self-reported } \\
\text { and criminal } \\
\text { record }\end{array}$ & $\begin{array}{l}8 \text { cases } \\
12 \\
\text { controls }\end{array}$ & Canada & $\begin{array}{l}25,8 \text { (cases) } \\
25.2 \\
\text { (controls) }\end{array}$ & $\begin{array}{l}\text { Blood-T } \\
\text { cells and } \\
\text { monocytes }\end{array}$ & $\begin{array}{l}\text { Methylated DNA } \\
\text { Immunoprecipitation } \\
\text { + Microarray for } \\
\text { selected cytokines } \\
\text { and related } \\
\text { transcription factors }\end{array}$ & $\begin{array}{l}\text { transcription } \\
\text { factors of } \\
\text { cytokines: } \\
\text { NF-KB } \\
\text { NFAT5 } \\
\text { STAT6 }\end{array}$ & $\begin{array}{l}\text { increased inflammatory } \\
\text { responses }\end{array}$ \\
\hline $\begin{array}{l}\text { Guiliemin et al. } \\
{[17]}\end{array}$ & $\begin{array}{l}\text { Teacher } \\
\text { assessment }\end{array}$ & $\begin{array}{l}5 \text { female } \\
12 \text { male } \\
\text { cases } \\
19 \text { female } \\
25 \text { male } \\
\text { controls }\end{array}$ & Canada & $\begin{array}{l}25 \text { (Cases) } \\
24,19 \\
\text { (controls) }\end{array}$ & $\begin{array}{l}\text { Blood-T } \\
\text { cells }\end{array}$ & $\begin{array}{l}\text { Methylated DNA } \\
\text { Immunoprecipitation } \\
+ \text { Microarray ( } 20000 \\
\text { genes and } 400 \\
\text { miRNAs) }\end{array}$ & $\begin{array}{l}\text { Out of } 448 \\
\text { differently } \\
\text { methylated } \\
\text { genes, } \\
\text { Inflammatory } \\
\text { response } \\
\text { genes found } \\
\text { to be } \\
\text { significantly } \\
\text { effected }\end{array}$ & $\begin{array}{l}\text { increased inflammation } \\
\text { and increased risk for } \\
\text { respiratory diseases }\end{array}$ \\
\hline Provençal et al. & Self-reported & 8 cases & Canada & & Blood-T & Methylated DNA & IL10 & Incerased \\
\hline
\end{tabular}




\begin{tabular}{|c|c|c|c|c|c|c|c|c|}
\hline [18] & $\begin{array}{l}\text { and criminal } \\
\text { record }\end{array}$ & $\begin{array}{l}12 \\
\text { controls }\end{array}$ & & $\begin{array}{l}25,8 \text { (cases) } \\
25.4 \\
\text { (controls) }\end{array}$ & cells & $\begin{array}{l}\text { Immunoprecipitation } \\
+ \text { Microarray }(20000 \\
\text { genes and } 400 \\
\text { miRNAs) }\end{array}$ & $\begin{array}{l}\text { Signaling } \\
\text { pathway } \\
\text { genes } \\
\text { Cytokine } \\
\text { signaling } \\
\text { between } \\
\text { immune cells, } \\
\text { Leukocyte } \\
\text { extravasation } \\
\text { signaling, } \\
\text { MAPK } \\
\text { signaling etc. }\end{array}$ & $\begin{array}{l}\text { inflammation,increased } \\
\text { trans-endothelial } \\
\text { leukocyte migration, } \\
\text { epithelial permeability }\end{array}$ \\
\hline $\begin{array}{l}\text { Suderman et al. } \\
\text { [19] }\end{array}$ & $\begin{array}{l}\text { Confidential } \\
\text { questionnaire } \\
\text { (self- } \\
\text { reported) }\end{array}$ & $\begin{array}{l}12 \text { cases } \\
28 \\
\text { controls }\end{array}$ & GBR & $\begin{array}{l}45 \text { (all cases } \\
\text { and } \\
\text { controls) }\end{array}$ & Blood & $\begin{array}{l}\text { Methylated DNA } \\
\text { Immunoprecipitation } \\
\text { + Microarray (20533 } \\
\text { genes and } 489 \\
\text { miRNAs) and qPCR } \\
\text { for selected genes }\end{array}$ & $\begin{array}{l}\text { WNT } \\
\text { signaling } \\
\text { pathway }\end{array}$ & $\begin{array}{l}\text { Progression of } \\
\text { inflammation in asthma }\end{array}$ \\
\hline Labonte et al.[20] & $\begin{array}{l}\text { Childhood } \\
\text { abuse } \\
\text { interviews }\end{array}$ & $\begin{array}{l}25 \text { cases } \\
16 \\
\text { controls }\end{array}$ & Canada & $\begin{array}{l}37,3 \text { (cases) } \\
40,9 \\
\text { (controls) }\end{array}$ & Brain & $\begin{array}{l}\text { Whole genome } \\
\text { methylation arrays }\end{array}$ & $\begin{array}{l}\text { RGS3 } \\
\text { HCK }\end{array}$ & $\begin{array}{l}\text { Abolished T cell migration, } \\
\text { inability of the cells to } \\
\text { undergo the cytoskeletal } \\
\text { reorganization required } \\
\text { for mediator release }\end{array}$ \\
\hline $\begin{array}{l}\text { Schwaiger et al. } \\
{[21]}\end{array}$ & $\begin{array}{l}\text { Childhood } \\
\text { trauma } \\
\text { questionnaire }\end{array}$ & $\begin{array}{l}30 \text { cases } \\
30 \\
\text { controls }\end{array}$ & Germany & $\begin{array}{l}52,57 \\
\text { (cases) } \\
51,47 \\
\text { (controls) }\end{array}$ & $\begin{array}{l}\text { Blood- } \\
\text { Monocytes }\end{array}$ & $\begin{array}{l}\text { Whole genome } \\
\text { methylation arrays }\end{array}$ & $\begin{array}{l}\text { NFKB } \\
\text { STAT1 } \\
\text { CREB }\end{array}$ & $\begin{array}{l}\text { Impaired regulation of } \\
\text { cytokine activity, } \\
\text { abnormal allergic } \\
\text { responses }\end{array}$ \\
\hline Cicchetti et al. [22] & $\begin{array}{l}\text { Child } \\
\text { protective } \\
\text { services }\end{array}$ & $\begin{array}{l}298 \text { cases } \\
250 \\
\text { controls }\end{array}$ & USA & $\begin{array}{l}9,4 \\
\text { (SD:0.88) }\end{array}$ & Saliva & $\begin{array}{l}\text { SNP genotyping, and } \\
\text { methylation assays } \\
\text { for selected regions }\end{array}$ & $\begin{array}{l}\text { ALDH2 } \\
\text { NR3C1 }\end{array}$ & $\begin{array}{l}\text { Premature lung agigng, } \\
\text { decreased suppression of } \\
\text { inflammation }\end{array}$ \\
\hline Cecil et al. [23] & Childhood & 84 cases & England & & Buccal & Whole genome & RPTOR & Impaired inflammation \\
\hline
\end{tabular}




\begin{tabular}{|c|c|c|c|c|c|c|c|c|}
\hline & $\begin{array}{l}\text { trauma } \\
\text { questionnaire }\end{array}$ & $\begin{array}{l}40 \\
\text { controls }\end{array}$ & & $\begin{array}{l}16-24 \\
\text { years }\end{array}$ & $\begin{array}{l}\text { epithelial } \\
\text { cells }\end{array}$ & methylation arrays & & and cell regulation \\
\hline Kaufman et al. [24] & $\begin{array}{l}\text { Recruited } \\
\text { from a } \\
\text { reported } \\
\text { maltreated } \\
\text { children } \\
\text { cohort } \\
\end{array}$ & $\begin{array}{l}122 \text { cases } \\
112 \\
\text { controls }\end{array}$ & USA & $\begin{array}{l}\text { 11,5 (SD: } \\
1,9)\end{array}$ & Saliva & $\begin{array}{l}\text { Whole genome } \\
\text { methylation arrays }\end{array}$ & CXCL10 & $\begin{array}{l}\text { impaired eosinophil } \\
\text { activation, increased } \\
\text { asthma exacerbation }\end{array}$ \\
\hline Marzi et al. [25] & $\begin{array}{l}\text { Childhood } \\
\text { trauma } \\
\text { questionnaire }\end{array}$ & $\begin{array}{l}1669 \\
\text { samples } \\
\text { (from } \\
2232 \\
\text { twins) } \\
\end{array}$ & USA & 18 & Blood & $\begin{array}{l}\text { Whole genome } \\
\text { methylation arrays }\end{array}$ & $\begin{array}{l}\text { No } \\
\text { significance } \\
\text { after } \\
\text { corrections }\end{array}$ & $\mathrm{n} / \mathrm{a}$ \\
\hline $\begin{array}{l}\text { Hautepen et al. } \\
{[26]}\end{array}$ & $\begin{array}{l}\text { Confidential } \\
\text { questionnaire } \\
\text { and self- } \\
\text { reported }\end{array}$ & $\begin{array}{l}780 / 552 \\
\text { two } \\
\text { cohorts }\end{array}$ & UK & $\begin{array}{l}47 \text { (cases) } \\
53 \\
\text { (controls) }\end{array}$ & $\begin{array}{l}\text { Buccal } \\
\text { cells } \\
\text { Blood }\end{array}$ & $\begin{array}{l}\text { Epigenome wide } \\
\text { analysis (EWAS) }\end{array}$ & $\begin{array}{l}\text { TONSL } \\
\text { (IKappaBR) } \\
N P Y\end{array}$ & $\begin{array}{l}\text { Regulation of the } \\
\text { expression of } \\
\text { inflammatory mediators } \\
\text { Early onset asthma }\end{array}$ \\
\hline $\begin{array}{l}\text { Marinova et al. } \\
{[27]}\end{array}$ & $\begin{array}{l}\text { Childhood } \\
\text { trauma } \\
\text { questionnaire }\end{array}$ & $\begin{array}{l}30 \text { cases } \\
15 \\
\text { controls }\end{array}$ & Switzerland & $\begin{array}{l}75,9 \text { (cases) } \\
72,8 \\
\text { (controls) }\end{array}$ & Buccal & $\begin{array}{l}\text { Whole genome } \\
\text { methylation arrays }\end{array}$ & $\begin{array}{l}\text { MTOR } \\
\text { ATP2A3 } \\
\text { ZC3H12D } \\
\text { PLXNB1 } \\
\text { ROBO1 }\end{array}$ & $\begin{array}{l}\text { Increased inflammation, } \\
\text { increased risk for obesity } \\
\text { related asthma, } \\
\text { increased intracellular } \\
\text { calcium } \\
\text { Lymphocyte activation }\end{array}$ \\
\hline Khulan et al. [28] & $\begin{array}{l}\text { Childhood } \\
\text { trauma } \\
\text { questionnaire }\end{array}$ & $\begin{array}{l}83 \text { cases } \\
83 \\
\text { controls }\end{array}$ & Finland & $\begin{array}{l}64 \text { (cases) } \\
62,9 \\
\text { (controls) }\end{array}$ & Blood & $\begin{array}{l}\text { Whole genome } \\
\text { methylation arrays }\end{array}$ & $\begin{array}{l}\text { FOXP4 } \\
\text { CADM1 }\end{array}$ & $\begin{array}{l}\text { Airway hyperactivity } \\
\text { Airway smooth muscle } \\
\text { proliferation }\end{array}$ \\
\hline
\end{tabular}




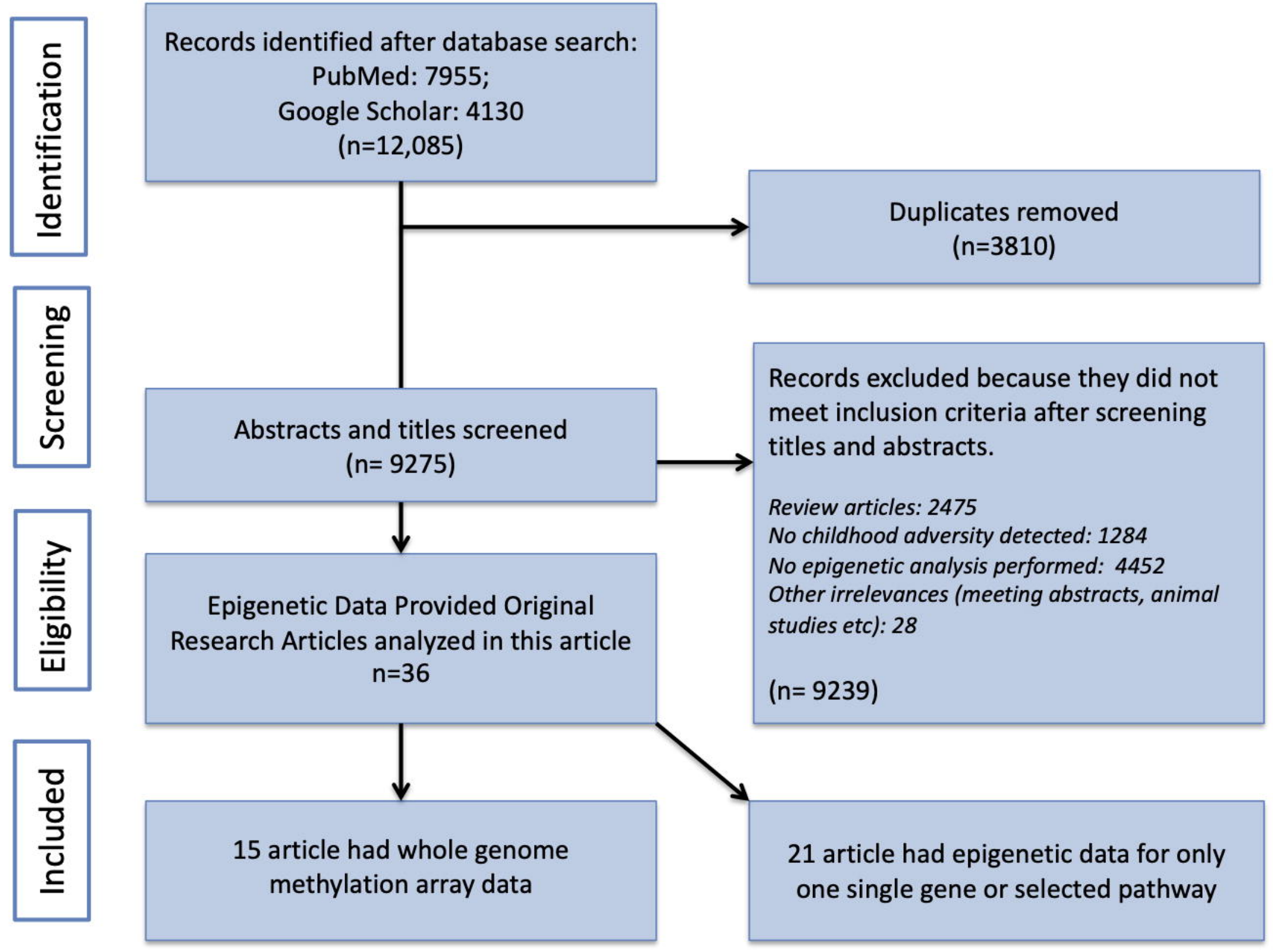




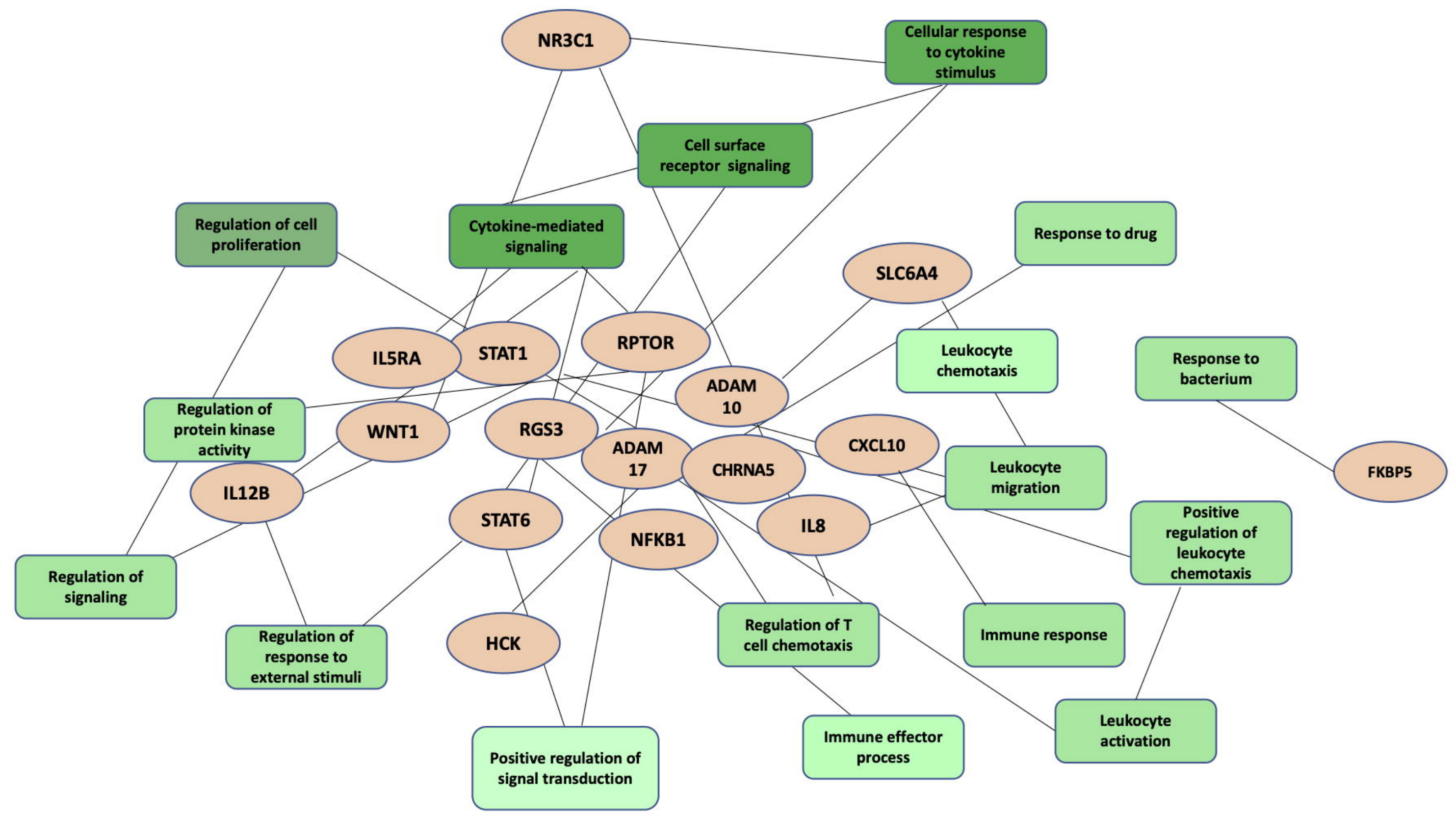

